\title{
Concerns About Mesenchymal Stem Cell Therapy
}

\author{
Mahsa Haseli ${ }^{*}$, Akbar Esmaeili $^{2}$ \\ ${ }^{1}$ Ralph E. Martin Department of Chemical Engineering, University of Arkansas, 3202 Bell Engineering Center, Fayetteville, \\ AR 72701, USA \\ ${ }^{2}$ Department of Chemical Engineering, North Tehran Branch, Islamic Azad University, Tehran, Iran
}

*Correspondence to

Mahsa Haseli, Ralph E. Martin Department of Chemical Engineering, University of Arkansas, 3202 Bell Engineering Center, Fayetteville, AR 72701, USATel: +98 121484813; Fax: +98-21-77009848, Email: akbaresmaeili@yahoo.com; mhaseli@uark.edu

Published online December 30, 2020

\section{Dear Editor,}

Multipotent mesenchymal stromal cells (MSCs), because of their potential for treating diseases, have gained considerable attention over the past 30 years for their immunosuppressive properties and tissue regeneration

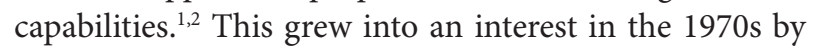
Friedenstein and contemporaries after studying the bone marrow. ${ }^{3}$ MSCs are an excellent candidate for cell therapy because of having intrinsic differentiation potentials into bone, cartilage and fat cells not found previously in other cells. They can also be isolated and expanded easily in vitro, and produce abundant useful growth factors and cytokines. ${ }^{2,4}$

Mesenchymal stem cells have become the top used stem cell type for clinical application with encouraging results. ${ }^{5,6}$ Significant progress has been made in stem cell research in recent years. The main therapeutic effects of MSCs are now attributed to the stimulation of several innate repair processes in injured tissues in vivo by secreted factors as well as the immunomodulation response. Therefore, MSC therapy is expected to find clinical application in human diseases. ${ }^{6,7}$ However, there are some critical issues that need to be addressed before MSCs can be used for clinical therapy in humans which will help determine the efficiency of cells administered to the patients as a therapeutic approach, most important of which is immunosuppressive properties. ${ }^{89}$ MSCs can be affected by tumor support that may affect potential tumorigenesis after MSCs transplantation, including different donors and tissues, inconsistent protocols, varying dosages and differing transfusion patterns, and mechanisms that control the behavior of the MSCs at the target site. ${ }^{10,11}$ Because of their unique features, stem cells are undoubtedly a great hope for the treatment of many diseases. More research is developing on the potential long-term risks associated with MSC therapy. However, Additional studies would also be a major contribution to stem cell biology in general as well as their transplantation.

\section{Conflict of Interest}

The authors declare that they have no conflict of interests.

\section{Ethical Statement}

Not applicable.

\section{References}

1. Castilla-Casadiego DA, Reyes-Ramos AM, Domenech M, Almodovar J. Effects of physical, chemical, and biological stimulus on h-MSC expansion and their functional characteristics. Ann Biomed Eng. 2020;48(2):519-35. doi: 10.1007/s10439-019-02400-3.

2. Pittenger MF, Discher DE, Péault BM, Phinney DG, Hare JM, Caplan Al. Mesenchymal stem cell perspective: cell biology to clinical progress. NPJ Regen Med. 2019;4(1):22. doi: 10.1038/s41536-019-0083-6.

3. Kfoury Y, Scadden DT. Mesenchymal cell contributions to the stem cell niche. Cell Stem Cell. 2015;16(3):239-53. doi: 10.1016/j.stem.2015.02.019.

4. Gao F, Chiu SM, Motan DA, Zhang Z, Chen L, Ji HL, et al. Mesenchymal stem cells and immunomodulation: current status and future prospects. Cell Death Dis. 2016;7(1):e2062. doi: 10.1038/cddis.2015.327.

5. Hmadcha A, Martin-Montalvo A, Gauthier BR, Soria B, Capilla-Gonzalez V. Therapeutic potential of mesenchymal stem cells for cancer therapy. Front Bioeng Biotechnol. 2020;8:43. doi: 10.3389/fbioe.2020.00043.

6. Andrzejewska A, Lukomska B, Janowski M. Concise review: mesenchymal stem cells: from roots to boost. Stem Cells. 2019;37(7):855-64. doi: 10.1002/stem.3016.

7. Wei X, Yang X, Han ZP, Qu FF, Shao L, Shi YF. Mesenchymal stem cells: a new trend for cell therapy. Acta Pharmacol Sin. 2013;34(6):747-54. doi: 10.1038/aps.2013.50. 
8. Lee SH. The advantages and limitations of mesenchymal stem cells in clinical application for treating human diseases. Osteoporos Sarcopenia. 2018;4(4):150. doi: 10.1016/j. afos.2018.11.083.

9. Esmaeili A, Haseli M. Optimization, synthesis, and characterization of coaxial electrospun sodium carboxymethyl cellulose-graft-methyl acrylate/poly(ethylene oxide) nanofibers for potential drug-delivery applications. Carbohydr Polym. 2017;173:645-53. doi: 10.1016/j. carbpol.2017.06.037.

10. Musiał-Wysocka A, Kot M, Majka M. The pros and cons of mesenchymal stem cell-based therapies. Cell Transplant. 2019;28(7):801-12. doi: 10.1177/0963689719837897.

11. Esmaeili A, Haseli M. Electrospinning of thermoplastic carboxymethyl cellulose/poly(ethylene oxide) nanofibers for use in drug-release systems. Mater Sci Eng C Mater Biol Appl. 2017;77:1117-27. doi: 10.1016/j.msec.2017.03.252.

Citation: Haseli M, Esmaeili A.concerns about mesenchymal stem cell therapy . Clin Neurosci J. 2021;8(1):1-2. doi:10.34172/icnj.2021.01. 